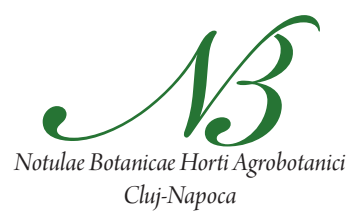

\title{
Developments in the Romanian Forestry and its Linkages with other Sectors
}

\author{
Ioan Vasile ABRUDAN ${ }^{1)}$, Viorel MARINESCU ${ }^{1)}$, Ovidiu IONESCU ${ }^{1)}$ \\ Florin (ORAS'), Sergiu Andrei HORODNIC ${ }^{3}$, Radu SESTRAS ${ }^{4}$ \\ 1) Transilvania University, 1 Sirul Beethoven St., 500123 Brasov, Romania; abrudan@unitbv.ro \\ 2) Buckinghamshire New University, Queen Alexandra Road, Bucks HP11 2JZ - High Wycombe, United Kingdom; Florin.Ioras@bucks.ac.uk \\ 3) University “Stefan cel Mare”, 13 University St., 720229 Suceava, Romania; horodnic@usv.ro \\ 4) University of Agricultural Sciences and Veterinary Medicine, 3-5 Manastur St., 400372 Cluj-Napoca, Romania; rsestras@yahoo.co.uk
}

\begin{abstract}
The evolution of the forestry sector in the last two decades in Romania has been significantly influenced by the post 1989 political and economic changes, forest restitution and the European Union accession process. Based on the analysis of forestry statistics, legislation and institutional changes this paper underlines the main developments in the forestry sector in the last twenty years and the linkages with other sectors that had an impact on its development. The significant change in forest ownership (based on which $45 \%$ of the Romanian forest is nowadays in non-state hands), the unprecedented re-organisation of the forest sector through the institutional separation of the regulatory, control and forest management functions, the changes in forest administration (including the establishment of more than 110 private forest districts) and the full privatisation of the wood harvesting and processing sector complemented by foreign investments have shaped the forest sector development in a context in which the forest resource remained almost unchanged. Major developments have been recorded in the establishment and management of large protected areas as National Forest Administration Romsilva is currently administrating 22 national and nature parks. Both positive and negative interactions of forestry with environmental protection, wood processing, agriculture, rural development, road infrastructure and tourism sectors have also impacted the evolution of the forest sector. Development policy options recommended by authors include among others the strengthening of the public authority responsible for forestry, reorganisation of the state forest administration and supporting the access of forest owners to the national and EU funding and compensation schemes for forestry.
\end{abstract}

Keywords: cross-sectoral, forest policy, land restitution, Romania

\section{FORESTRY SECTOR: BASIC FACTS}

Romania's forests and other wooded lands cover about $29 \%$ of the country (for the main features see Table 1) and include some of the largest tracts of natural forests still remaining in Central and Eastern Europe.

Forests have had an important role in Romania's economic development, especially in the rural area, providing an important source of income from wood harvesting, wood processing and non-timber forest product industries (Poynton et al., 2000). Compared to other countries in Central and Eastern Europe, forestry based sector and industries are still a significant contributor to the national economy: $3.5 \%$ contribution to GDP in 2007 (UNECE, 2009).

\section{Forest area}

According to the provisions of the recently approved Forest Code (Law 46/2008), forest is defined as an area of minimum 0.25 ha covered by trees whose height at maturity is at least $5 \mathrm{~m}$, under normal growing conditions. All
Tab. 1. Main features of Romania's forests

\begin{tabular}{cc}
\hline Total forest and other wooded land area & 6.649 million ha \\
\hline Forest ownership (June 2009): & \\
\hline State-owned forests & $55 \%$ \\
Non-state forests & $45 \%$ \\
Forest types: & $30 \%$ \\
\hline Coniferous (especially spruce) & $31 \%$ \\
Beech & $18 \%$ \\
Oaks & $21 \%$ \\
\hline Other & 1,347 million $\mathrm{m}^{3}$ \\
\hline National forest stock & $5.4 \mathrm{~m}^{3} / \mathrm{ha}-\mathrm{year}$ \\
\hline Annual growth & \\
\hline Geographical distribution of forests: & $65 \%$ \\
Mountains & $27 \%$ \\
Hills & $8 \%$ \\
\hline Plains & $51 \%$ \\
\hline Functional distribution (2009): & $49 \%$ \\
\hline Protection forests (not protected areas) & 161 thousands ha \\
\hline Production forests & \\
\hline Forest area with no active intervention &
\end{tabular}


such areas are included in the so called "national forest fund". It is also considered forest the area covered by forest protection belts, dwarf pine communities and the meadows covered by trees with a canopy closure index higher than 0.4 (Law 46/2008). Forest area has remained approximately unchanged in the last two decades in Romania: 6.6-6.7 million ha of forests and land partially covered by forests (National Institute of Statistics 1991, 2008). The slight fluctuations of statistical data for the last two decades reflect the statistical reporting inconsistencies rather than the real changes in the forest and forest land area in Romania. However, a slight increase in the afforestation of degraded agricultural lands after 2000 should be noticed (Abrudan et al., 2003; Abrudan, 2006).

\section{Forest ownership}

After the fall of communist regime in December 1989, the Government embarked on a program of land restitution. As an initial measure, under Law 18/1991, approximately 353,000 hectares of forest land were returned to around 400,000 pre-1948 individual owners (up to 1ha per owner). In 2000, another land restitution law (Law $1 / 2000$ ) was passed by the Parliament and according to this law all community, town and communal forests should be restituted to their former owners. The restitution was limited to 10 ha for individuals and 30 ha for churches, even if the size of their ownership before the 1948 nationalization was larger than these imposed limits; protected forests were exempted from restitution. The third restitution law (Law 247/2005) was passed in 2005 and according to its provisions all forest (including protected areas) should be restituted to the former owners irrespective of size, location and ownership type. Although not finalised yet, the implementation of the restitution laws determined a significant change in forest ownership in Romania: by the end of June 2009, more than $45 \%$ of the Romanian forests were in non-state ownership and it is foreseen that, at the end of the restitution process, approximately $60 \%$ of the country's forests will be owned by other owners than the state (Regia Nationala a Padurilor Romsilva, 2009).

\section{Forestry production}

In the period 1991-2008 the annual allowable cut varied between 15.5 and 18.5 million $\mathrm{m} 3$. It has never been exceeded by the actual harvest, excepting 1996, as a result of 1995 windthrow (Abrudan et al., 2005).

The harvesting and wood processing sector is fully privatised and there are more than 300 enterprises with more than 50 employees performing timber processing (except furniture sector) whilst the number of wood processing companies employing less than 50 employees exceeded 5,000 in 2005 (National Institute of Statistics, 2006). In 2005 there were about 2,900 companies which produced furniture or component parts for furniture.

About 28,000 people were employed in 2000 in forest administration and management, circa 15,000 in wood harvesting, 67,000 in the woodworking industry, 21,000 in the pulp and paper industry and 104,000 in the furniture industry (Istratescu et al., 2001). By 2008, the total number of employees in the forest based sector and industries decreased to circa 161,000 (UNECE, 2009). In the period 1991 - mid 2009, the number of employees in state forest management (National Forest Administration NFA Romsilva) decreased from 39,561 in 1991 to 27,098 in 1999 and about 21,400 in mid 2009 (Regia Nationala a Padurilor Romsilva, 2009). Whilst the significant reduction in the period 1991-1999 was due to the restructuring of NFA Romsilva and the externalisation of some of its previous activities, afterwards the restitution of forests has been another factor which affected the decrease of jobs in state forest administration.

The contribution of the forestry (including the processing sector) to GDP ranged between 3.5 and $4.5 \%$ in the last decade (National Institute of Statistics, 19992008). The export value and volume of wood products and furniture increased continuously in the last ten years, despite some fluctuations of pulp, paper and cardboard export (Ioras and Abrudan, 2006). The annual export value of forest products in the last three years (including processed timber and furniture) exceeded 2 billion US\$ making Romania a net exporter of wood based products. For example, in the recent years Romania exported about $80 \%$ of its furniture production and the export of furniture was mainly directed to the major markets of the world: Germany, France, Holland, Italy, Austria, Great Britain, USA etc. (Cismaru, 2005).

The non-pecuniary values of forests are, however, considerably larger than the financial values, but traditional accounting methods have tended to mask this. A study commissioned by the World Bank in 1999 (Poynton et al., 2000) showed that the annual value of products and services (including the environmental ones) provided by the Romanian forests was around 3.1 billion US $\$$.

\section{Forest and nature conservation}

The Romanian Network of Protected Areas covers more than 1.65 million ha or about $6.9 \%$ of the country's area. Apart from the Danube Delta Biosphere Reserve there are other 27 large protected areas - national parks and nature parks ( 22 of them administrated by NFA Romsilva), including 134 nature reserves and natural monuments, and covering 1.17 million ha. More than 693 nature reserves and natural monuments are outside the large protected areas and cover 102,534 ha (Borlea et al., 2006; Abrudan et al., 2005). About $10.4 \%$ of the national forest area is included in the national and nature parks and 160.429 ha of forests are strictly protected.

Before 1999 none of the large protected areas had legally established administrative structures in place, except Danube Delta Biosphere Reserve. This situation was due to the poor capacity of the state budged to finance the administration of protected areas. Under these circumstanc- 
16

es the only effective legal tool to protect the forests within the protected areas had been the forest management plan. According to the provisions of the forest management plans about 477,000 ha of forests were included in the national network of protected areas and around a third of them were strictly protected

In 1999 the World Bank - GEF funded Biodiversity Conservation Management Project became effective and administrations for three large protected areas (Retezat National Park, Piatra Craiului National Park and Vanatori Neamt Natural Park - a new protected area) were established within the NFA Romsilva, as part of the three main objectives of the Project: (1) Strengthening the national framework for biodiversity conservation; (2) Developing models for protected areas management, and (3) Building public support for biodiversity conservation (World Bank 1999). Despite the fact that the development of effective management plans for other five protected areas (Ceahlau, Balta Mica a Brailei, Portile de Fier, Apuseni and Muntii Macinului) had been supported by international projects (Life Natura, Global Environmental Facility - GEF etc.), none of them had legally established administrative structures.

In early 2002 the Board of NFA Romsilva decided the establishment of the administrations for all national and natural parks under its Protected Areas Service, considering that in all of them the majority of the area is covered by forests. However, this was an internal decision and although it had significantly contributed to the improvement of nature protection infrastructure, the public authority responsible for environmental protection had not approved officially the establishment of these administrations.

One year later, a legislative development in nature protection and protected area administration - the "Governmental Decision 230/2003 regarding the delineation of the biosphere reserves, national parks and natural parks and the establishment of their administrations", approved in March 2003 - created the proper framework for the administration of large protected areas. The administrative structures could be either (a) in the subordination of the public authority responsible for the environmental protection or (b) under the coordination of the public authority responsible for the environmental protection, based on a contract with bodies capable to prove their technical, scientific, administrative and financial capacity for protected areas administration. It also mentioned that the main land owner in a protected area had the right to administer the respective protected area (on a contractual basis) if the above mentioned capacity is proved. The minimum duration for the administration contracts is 10 years.

Under these new circumstances, the NFA Romsilva submitted its offer for the management of the national and nature parks and since February 2004 the public authority for environmental protection assigned the management of
22 national and nature parks to NFA Romsilva, on a contractual basis.

\section{FOREST SECTOR DEVELOPMENT AND ITS MAIN LINKAGES WITH OTHER SECTORS}

Sustainable forest management and the development of the forest sector in Romania is affected by three categories of factors: (a) internal factors, residing within the forest sector itself, (b) external factors, residing outside the forest sector and (c) international processes, including the EU membership (Abrudan et al., 2005). Considering the direct and indirect linkages between them, each of these categories of factors can be hardly separated from the others.

The internal factors affecting the forest sector are mainly linked to the wood resource, the wood market and the institutional arrangements for forest management and administration.

There have been no significant changes in the wood resource in Romania in the last decades, as the forest area and species composition remained almost unchanged. However, due to the slightly unbalanced age classes and the selective harvesting of valuable species in some parts of the country, it is expected that the size and quality of wood to be harvested on a medium-long term will decrease. On the other hand, the recent restitution of about $45 \%$ of the Romanian forests might lead to an increased harvest and wood supply from these forests - mainly for economic reasons - compared to the previous management practiced by the NFA Romsilva, which had an important ecological/ protection component.

Despite the fact that the average price of wood (standing or roadside) has increased almost continuously after 1990, as it was lower than in other Central and Western European countries, it is hard to anticipate its evolution in the future. On a medium term it might be possible that the prices for standing or roadside wood in Romania would become similar to those in other Central European countries. As Romania is a net exporter of wood and wood products the international evolution of wood product prices will clearly have an impact on the domestic market.

The institutional changes in the forestry sector have known a tumultuous evolution after 1990. If during the communist period the regulatory, supervisory and management of the state-owned forest property functions were in one hand (Ministry of Forests), in early 1990 the first two functions of the state were separated from the management function via the establishment of the NFA Romsilva (reorganized several times since then).

Department of Forests (within the Ministry of Environment before 2001 and the Ministry of Agriculture afterwards) has been the public authority responsible for forests in Romania. In spite of the many changes, the regu- 
latory and supervisory/support functions were contained in different directorates of the Department of Forests.

In 1999 the Forest Inspectorates were established, initially with 7 territorial branches, which were expanded to 16 branches in 2001, as the restitution process was imminent. Their function was to enforce at regional level the supervision/support functions of the public authority for forests. Due to the Cabinet re-organization, in spring 2003 the Forest Inspectorates were transferred to the National Environmental Guard within the National Authority for Control and left the Department of Forests without any territorial structures. This situation changed in January 2004, when Territorial Inspectorates for Forest Regime and Hunting were established in each of the 8 development regions of the country and the capital.

The Department of Forests has faced some difficulties regarding the capacity and physical resources to undertake its roles and staffing has not reached the initial planned level due to budgetary constraints.

The National Forest Administration Romsilva administrates and manages the state forests and is a legal stateowned entity with an essentially commercial mandate. It has 42 branches and more than 360 forest districts and operates as a financially autonomous organization performing forest management and silvicultural operations, engaging in non- timber forest products and services. It undertakes a wide range of public purpose activities and is responsible for the management of protected forest areas and national parks, which have been functioning since early 2009 as distinct legal entities. NFA Romsilva also has in its administrative structure the Forest Research and Management Planning Institute.

The NFA Romsilva is, like many state-owned organizations, coming under increasing political pressure and public scrutiny regarding the stewardship of state assets under its management. Forest restitution has already reduced the state forest area managed by NFA Romsilva by up to $45 \%$ with consequent reduction in revenues and the greater impact on fixed costs. The focus to date, despite the major issues facing the company, has been principally on staffing at branch and district offices and less on processes, operational efficiency and exploring choices or options for its strategic development.

An important institutional milestone in the evolution of the forestry sector in Romania after the fall of communism was the establishment of the first private forest district (an administrative/management structure for private forests, similar to those of NFA Romsilva) in spring 2002. Since then, more than 110 private forest districts have been established (managing more than 1.1 million ha of forests) and in 2004 they established an umbrella association named Association of Forest Administrators from Romania. The number of private forest districts is expected to increase in the coming years, in parallel with the reduction of NFA Romsilva forest districts, as a consequence of the restitution process. Although NFA Romsilva will remain the main player in forest management in Romania, the private forest districts will play an increasing role in the Romanian forest sector and on the wood market.

The Association of Private Forest Owners (APPR) is a national umbrella organization established in 1998 and representing all categories of private forest owners in Romania. Its membership includes local and county associations, communes, town halls and individual members. The APPR has an important role to play in promoting sustainable management of restituted forests as their owners or applicants under the restitution program are unaware not only of their rights and obligations but also of the value to be derived from the sale of timber and other products and the importance of sustainable forest management. Despite its important role, APPR is facing financial and staffing problems as well as conflicting discussions between its different types of members.

Regarding the external factors, residing outside the forest sector it should be mentioned that there is a complex network of public policies and legislation which directly and indirectly affects the development of the forest sector in Romania: (a) policies establishing the institutional framework, (b) policies related to specific economic sectors, and (c) policies promoting development (Abrudan, 2002).

In the last two decades the economic situation (and especially economic growth) has significantly affected the forestry sector, including forest management. For example, the years of econom-ic decline in the 90's have negatively impacted on the activity of logging and processing companies and indirectly reduced the volume and quality of forest operations, as well as the income of the NFA Romsilva and its investment capacity. This situation has changed in the last ten years and the improvement of the economic situation is expected to continue. On the other hand, the budget allocation for forestry has been limited and many of the Governmental programmes related to forestry were only partially achieved.

The restitution of forest land and the privatization of wood harvesting, transport and processing sector have probably had the highest impact on the evolution of the forestry sector and forest management in Romania. The size of the restituted forests according to Law 18/1991, which in many cases represented only part of the pre-nationalization individual ownership, created frustration among forest owners. In addition, the poor capacity to enforce the forest legislation and to raise forest owners' awareness on sustainable forest management resulted in significant environmental damages in private forests. Although private forest management structures have been established, the general opinion is that in the short term, the forests restituted according to the 2000 and 2005 restitution laws, will face some management difficulties. The reasons for this include: lack of capacity and knowledge; vested interest in gaining immediate economic benefits; and improper law enforcement capacity. 
18

The completed privatization of wood harvesting, transport and processing has had mainly positive effects on forest management. Privatization resulted in a higher competition for wood resources and increased prices for standing wood, with direct financial benefits for NFA Romsilva.

The public financing has a direct impact on the development of the forestry sector as the regulatory, control and extension functions of the state are depending on the annual budget allocation. Budgetary allocation for forest sector has been relatively small in the last two decades, thus particularly affecting the control and extension functions, as well as the public authority staff quality and commitment. A significant improvement resulted from the implementation of the World Bank Forest Development Project (2003-2009), which provided resources for equipment, vehicles and training for forest inspectorates.

In previous years the agricultural policies and legislation have had some important influences on forest sector development. An important aspect of Romanian forestry is that any agricultural policy and regulation must not lead to the reduction of the public forest area. Indeed the afforestation of degraded agricultural land has been a stated priority within the Governmental policy to increase the forest cover. Such priorities also agree with EU agricultural and rural development policies, given that Romania's forest cover per capita is presently lower than the EU average. Some agricultural policies as well as agricultural activities have negative effects on forests and forest management. Despite being forbidden by law, grazing represents by far the main problem, and the capacity to enforce the legislation in this respect should increase.

Game management and hunting legislation are also impacting on forest management. According to the existing legislation the central public authority for game management assigns the game management right to the legally established hunting organizations. This provision has created some conflicts between hunting organizations and private agricultural and forest land owners, so this situation should be addressed in the near future.

The last decades have been characterized by an almost continuous dispute between the ministry responsible for forest management and the public authority responsible for wood harvesting and processing. While the first one has taken measures towards a better use of forest resources, free competition for wood resources and harvesting methods fulfilling ecological requirements, the latter has been fighting and lobbying for a cheap resource and advantageous contractual terms for wood harvesting. In early 2001, the Cabinet approved the supervision of the reserve price for standing wood that the NFA Romsilva sold by auction. This was perceived as a state intervention to control the standing wood price in areas where the competition for wood resource is low, so it was removed five years later, as it is not common in a free-market economy.

In the period 1990-2000, forests, environmental protection and water management were under the same public authority (ministry) and as a result of this situation there were no major conflicts between these sectors. The environmental protection strategies have included strategic objectives with direct positive influence on forest development: extension of forest area; establishment of forest belts in areas exposed to desertification; afforestation of degraded agricultural land and improvement of the legislation on forest protection. In 2001 the forests were moved under the authority of the ministry responsible for agriculture and since then there have been several major disputes between the environment and agriculture ministries; these were mainly related to the legislation initiatives regarding forest and wildlife protection, delineation and management of protected areas as well as the designation of Natura 2000 network.

There have been many linkages between forestry and nature conservation in the last century. While intensive logging had negative impacts on nature conservation in the first half of the twentieth century, the close to nature approach that has been practiced extensively since the 1950s in Romanian forestry has reduced such impacts. Many forest ecosystems and wildlife species have been preserved due to the efforts of foresters. Forest organisations have also been largely involved in most of the processes, programs and activities related to nature conservation in the last decades, including the establishment of the administrations for the first large protected areas in the Romanian Carpathians. Despite the fact that foresters and forest organizations have significantly contributed to nature conservation, there have also been situations when their actions have had negative impacts. There are examples of negative cumulative effects of harvesting on water quality, flora and fauna. However, in the last decade foresters have increasingly become more open to the dialogue with conservation organizations and the general public on nature conservation issues. The strong involvement of NFA Romsilva in the management of the vast majority of large protected areas in Romania will certainly improve its nature conservation skills as well as its cooperation with other stakeholders.

There are close linkages between tourism and forestry, especially in the Carpathian region and recently the cooperation between the public authorities responsible for tourism and forestry has improved significantly. The national authority for tourism participated actively in the development of the National Forest Policy and Strategy. The development of eco-tourism has become a priority action both for the forestry sector and the public authority responsible for tourism. While the presence of forest seems to have a positive impact on tourism, the latter has mainly had a relatively negative impact on forests: clearfelling to allow development and construction of hotels, restaurants, skiing facilities etc.; garbage left in the forest by tourists; illegal camping and picnicking; and forest fires caused by the negligence of tourists are relevant examples. 
Development and modernization of the road infrastructure (public and forest roads) have both negative and positive impacts on forest sector development. The negative impacts result from forest clear-felling to make room for new public roads or motorways. In many cases the Government approves the clear-felling and exempts the development from the land use change tax. On the other hand, the development of the transport infrastructure has a positive impact on forest management, as it provides better access to forest resources, both for harvesting and tending and maintenance operations.

Although there is no separate public authority responsible for rural development, this sector - coordinated by the ministry responsible for agriculture - is highly important, especially within the framework of the EU funding mechanisms. Romania developed a National Plan for Agriculture and Rural Development (NPARD) and significant EU support for the NPARD implementation in the period 2004-2006 was available to Romania under SAPARD. For the period 2007-2013, a National Plan for Rural Development (NPRD) was developed and EU is financially supporting its implementation. Some of the measures eligible for funding under SAPARD and NPRD are directly related to forestry and have a positive influence on forest sector development: afforestation of degraded agricultural lands, establishment of forest nurseries, construction of forest roads, modernization of wood harvesting and processing, establishment of local associations of private forest owners etc.

Forestry education and research play an important role in the development of the forestry sector. Forestry high schools and the higher education institutions provide the technical staff employed by the sector and also carry out forestry research. The development of forestry higher education programs in seven new universities in the last two decades and the recent year "inflation" of graduates of both medium and higher education institutions have impacted mainly negatively on the development of the forest sector. The negative effect resulted from the lower level of knowledge of the graduates. The quality of education was affected by the increased number of students, despite the fact that the higher competition for a job in the forest sector should lead to the employment of qualified staff. It is a clear need in a short-medium term to correlate the number of students funded by the state with the employment capacity of the forestry sector.

In recent years the fields of research have been adapted to the needs of the national and EU forest sector development. However, the research institute and the universities, like many other organizations with a mandate for forest research, are finding it increasingly difficult to source funding. While they have the professional and technical expertise to implement management planning and research, they need to increase their capability in identifying national and international funding lines, including private sector.
International processes regarding forest management or associated with forests have played and will continue to play an important role in the development of the forest sector. As signatory of several international conventions or agreements, Romania has the obligation to implement and enforce their provisions in the country.

The resolutions of the Pan-European Ministerial Conferences on the Protection of Forests, the Convention on Biological Diversity (1992) and the Kyoto Protocol (1997) are probably the international processes with the highest impact on the development of the forest sector in Romania, especially at the forest management level. Forest certification is also influencing the development of the forest sector and its benefits cannot be neglected in a country which is a net exporter of wood and wood products.

Integrating forest management and planning within the broader context of rural development, agriculture and landscape planning has become an important issue especially in the context of EU accession and membership.

Among issues with relevance to the forest sector in Romania as an accession and, after 2007, an EU member country, harmonisation of national legislation with the EU legal framework stand out. A high priority has been accorded to the relevant regulations concerning forests and forestry: protection of forests against atmospheric pollution and forest fire (the emphasis is on ensuring that arrangements for monitoring and prevention mechanisms are appropriate), the marketing of forest reproductive material, removal of market distortions and obstacles and the establishment of a European Forestry Information and Communication System (EFICS). Although not the direct responsibility of the forest sector, the establishment of the network of protected sites under the NATURA 2000 programme underpinned by the so-called "Habitats Directive" and "Birds Directive" have been also affected the sustainable management and conservation of forest areas. It should be emphasized that Romania's effort towards harmonization of national legislation and administrative arrangements with EU Directives and Regulations has led to a better inter-sectoral cooperation and coordination on specific cross-sectoral issues.

\section{POLICY OPTIONS}

In recent years the formulation of policy and development planning has been characterized by inter-administrative and governmental agency cooperation, as well as involvement of the main stakeholders, public participation and transparency. As many other sectoral policies, the $\mathrm{Na}$ tional Forest Policy and Strategy was developed through an open, transparent and participatory processes, coordinated by the public authority responsible for forests. The following stakeholder groups were involved in the process: public authorities for forests, environmental protection, agriculture, waters, industry and trade, tourism; state forest administration (all administrative levels); private forest 
20

owners (national and regional levels); private sector (forest management planning, logging, primary processing); Environmental Protection Agency; local governments and councils; Romanian Academy; research (forest management, logging, wood processing); education (universities); administrations of protected areas; non-governmental organizations; development organizations (World Bank, European Commission offices in Romania); general public; mass-media. The National Forest Policy and Strategy developed in 2000 and revised in 2005 is in accordance with the national development strategy, and includes clear policy statements and strategic objectives (see Box 1).

A series of priorities regarding the implementation of NFPS and the sustainable development of the forest sector should be addressed in a short and medium term.

The institutional strengthening of the Department of Forests should represent a priority for the development of the forestry sector. Apart from the strengthening of the existing Directorates within the Ministry of Agriculture, Forests and Rural Development, there is now an urgent need to support the normal functioning of the nine Territorial Inspectorates for Forest Regime and Hunting.

In the legislation development process the Department of Forests should enhance its collaboration and dialogue with the main forest stakeholders and interest groups (private owners, private sector, research and education, conservationists, NGOs etc.) in order to adequately reflect and represent their opinions and interests.

While presently about $45 \%$ of the Romanian forests are in non-state ownership, the role and mandate of the NFA Romsilva should be adapted to its new position in the Romanian forestry sector. The administrator of the state forests should reconsider its portfolio of activities and enhance its commercial mandate as it has to face the private sector competition. This would involve the development of its organizational, operational and commercial efficiency, as well as optimizing its contribution to the economy of Romania, through the sustainable management of state forest resources. The NFA Romsilva and the public authority responsible for agriculture should also decide on the position of the Forest Research and Management Planning Institute (ICAS) in the forestry sector as it is unusual to have such an institute within the state forest administration, especially after the approval of the Forest Code in 2008, which specifies that ICAS will become an independent national research institute.

The National Association of Private Forest Owners $(A P P R)$ as well as the local associations will play an important role in the management of private forests and the promotion of private owners' interests. APPR should be supported to fulfill its role in the sustainable development of restituted forests and their new forest owners through: facilitating the development and consolidation of local and county ownership associations; development and provision of extension services; facilitating access and drawdown of EU and national funding; lobbying at national level and public awareness at national and local levels.

With regard to future ownership, the maintenance of the ecological functions of the restituted forests (e.g. climate, soil and watershed protection, biodiversity etc.) should represent a priority, especially in the mountain areas. The development and enforcement of the appropriate regulations and the development of financial mechanisms (financial assistance/compensations, tax exemptions, etc.) to support sustainable forest management, as well as the development of alternative income generating activities in rural areas, are potential ways to achieve this objective. Such development will however require a concerted and coordinated effort of the Department of Forests, Territorial Inspectorates, private forest districts, APPR, local associations of private owners and the central and local authorities.

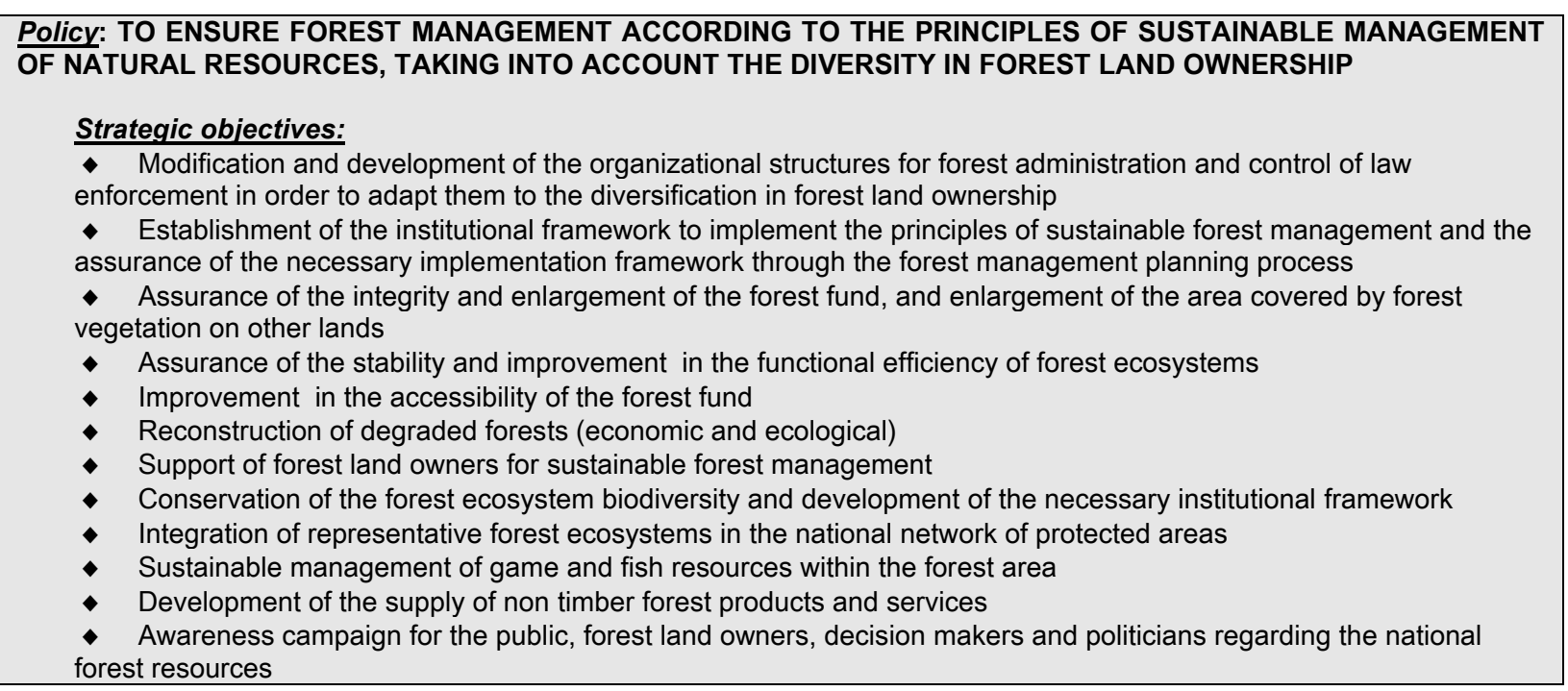

Box 1 . The policy statement and the strategic objectives included in the National Forest Policy and Strategy 
Considering the high production and protection value of Romanian forests and the public services provided by forest ecosystems, as well as the ongoing changes in forest ownership there is a strong need for a continuous public awareness campaign on sustainable management and conservation of forest resources. The campaign should target key stakeholders including: the general public, with particular emphasis on communities living in forested areas private forest owners (individuals and communities); Territorial Directorates; Government decision makers, and other influential groups.

\section{References}

Abrudan, I. V. (2002). Cross-sectoral linkages in Romanian forestry. Report prepared for the FAO Forestry Department, Policy and Planning Division, Policy and Institutions Branch, Rome.

Abrudan, I. V., C. Pahontu, F. Negrutiu and G. Florescu (2003). Aspects of afforestation work carried out in Romania, 19912001 (in Romanian). Padurea si viitorul, Brasov, p: 97-100.

Abrudan, I. V., V. Marinescu, G. Ignea and C. Codreanu (2005). Present situation and trends in Romanian forestry. Proceedings of the 6th IUFRO 6.13.00 Group Meeting: Legal Aspects of European Forest Sustainable Development. Ed. Universitatii Transilvania, Brasov, p: 157-171.

Abrudan, I. V. (2006). Afforestation (in Romanian) Ed. Universitatii Transilvania, Brasov.

Borlea, G., S. Radu and D. Stana (2006). Forest Biodiversity Preservation in Romania. Notulae Botanicae Horti Agrobotanici Cluj-Napoca 34(1):21-27.

Bouriaud, L. and I. V. Abrudan (2004). Recent forest policy developments in Romania and the main challenges ahead. p. 159-174. In: L. Jansky, R. Nevenic, I. Tikkanen and B. Pajari, (Eds.). Proceedings of the International Symposium on Challenges in Strengthening of Capacities for Forest
Policy Development in Countries in Transitions. United Nations University Press, Tokyo.

Cismaru, I. (2005). Wood Industry in Romania - Present and Perspectives. Proceedings of the $8^{\text {th }}$ International IUFRO Wood Drying Conference, Brasov, Romania: 3-8.

Ioras F. and I. V. Abrudan (2006). Romanian forestry sector - privatisation facts. The International Forestry Review $8(3): 361-367$.

Istratescu, C., A. Sereny and G. Parnuta, (2001). Romania's Forest Products Markets. Forest Products Annual Market Review 2000-2001. Timber Bulletin - Volume LIV (2001), No.3. FAO, UNECE, Rome, p: 21-32;

National Institute for Statistics (1991-2008). Romania. Statistical Yearbook. Bucuresti.

Poynton, S., A. Mitchell, G. Ionascu, F. Mc Kinnenn, J. Elliott and I.V. Abrudan (2000). Economic evaluation and reform of the Romanian forestry sector. Editura Pentru viata, Brasov.

Regia Nationala a Padurilor Romsilva (2003). Buletin informativ (oct. 2003). Bucuresti.

Regia Nationala a Padurilor Romsilva (2009): Raport de activitate pe semestrul I - 2009. Bucuresti.

UNECE-Timber Committee (2009). Data and Statistics. Forest Resources. Forest Products. http://timber.unece.org/index. php ?id $=84$.

World Bank (1999). Biodiversity Conservation Management Project. Project Appraisal Document. Washington DC.

World Bank (2001). Support for the Romania National Forest Policy and Strategy. Final Report. Washington DC.

World Bank (2003). Forest Development Project. Project Appraisal Document. Washington DC. 